\title{
AN OPTIMAL HARVESTING MODEL TO EVALUATE THE INDONESIAN SELECTIVE CUTTING SYSTEM (TPI) (Model pemanenan yang optimal untuk mengevaluasi tebang pilih Indonesia (TPI))
}

\author{
By/Oleh
}

\author{
Apul Sianturi
}

Ringkasan

\begin{abstract}
Pendapatan dari hutan alam dalam duapuluh tahun terakhir sangat berpengaruh dalam peningkatan. pendapatan masyarakat Indonesia. Hal ini akan terus berlangsung bila hutan alam dapat dikelola dengan berkesinambungan atau lestari. Salah satu elemen penting agar hutan alam dapat lestari dalam memberikan hasil adalah dengan meninggalkan cukup tegakan tinggal yang sehat pada setiap kali mengadakan tebang pilih.

Tujuan dari study ini adalah untuk mengevaluasi sistim Tebang Pilih Indonesia (TPI), terutama dalam kaitannya dengan rotasi tebang, banyaknya pohon yang ditebang, dan banyaknya pohon sehat yang ditinggalkan. Dalam menentukan pilihan yang terbaik digunakan maksimalisasi nilai hutan yang didapat dengan menyusun model program linear (linear programing). Pertumbuhan (growth) dari hutan alam setelah diadakan penebangan diproyeksikan dengan model matrik transisi. Pohon dikategorikan dalam dua grup yaitu diptrocarp dan non-diptrocarp, serta dalam 7 kelas diameter.

Model program linear digunakan untuk mensimulasi 7 macam rotasi tebang, 3 tingkat suku bunga, 3 tingkat kerusakan tegakan, dan 6 macam sistim royalty.

Hasil dari simulasi menunjukkan bahwa rotasi tebang yang optimal ditentukan oleh besarnya suku bunga serta tingkat kerusakan tegakan tinggal. Makin besar suku bunga yang digunakan makin pendek rotasi tebangan yang memberikan nilai hutan tertinggi, yang berarti bahwa penggunaan suku bunga yang tinggi memaksa untuk memanfaatkan sumber daya alam lebih cepat. Sebaliknya, bila kerusakan tegakan tinggal besar maka rotasi tebang harus lebih panjang.

Dalam pada itu jumlah pohon tinggal yang sehat, serta jumlah pohon yang ditebang ditentukan oleh rotasi tebang serta tingkat kerusakan tegakan tinggal. Makin panjang rotasi tebang makin banyak jumlah pohon yang dapat ditebang dan ditinggalkan. Sebaliknya, makin besar kerusakan tegakan tinggal yang diperbolehkan, makin sedikit jumlah pohon yang dipungut dan yang ditinggalkan sebagai tegakan tinggal.
\end{abstract}

\section{INTRODUCTION}

Indonesia has been fortunate to be endowed with extensive areas of valuable natural tropical forests, which are extremely complex ecosystems, and are richer in tree species than similar areas in Africa and South America (Whitmore, 1975). About 70 percent of the Indonesian land area is forest lands. Most of the forest areas are covered by natural forest which has an uneven aged stand structure.

The task of managing any forest is to tree to achieve stated management objectives in the most effective way. In order to do this the management objectives must be clearly defined, include the projection of expected yield, quality, composition, projected returns, and costs to enable the most effective method of attaining these objectives to be selected or developed.

By Indonesian law, forest resources are publicly owned and the Government is responsible for managing them for the maximum benefit of society, present as well as future generations. This is expilicitly stated in the Indonesian Basic Constitution of 1945 (UUD 1945) and is elaborated in the Ministry of Forestry objectives in each Five-Year National Development plan.

In order to achieve these national goals, the Government has been preparing steps to develop strategic plans for national forest development. One of the steps is by improving planning methods and techniques in order to facilitate efficiency in the management of national forests.

It is known that timber production is not, or should not be, the sole objective in managing forest, but it is the single most important objective of production forest which is one of the main types of Indonesian forest.

Over the past two decades this production forest has been harvested by the leasing of forest areas as concessions to logging compnies. The leasing agreement entitles them to utilize the timber products within their concessions areas. In managing their forest, companies are required to follow the Indonesian Selective Cutting System (TPI). 
The TPI system is a silvicultural system which includes timber harvesting and forest regeneration. There are four main factors which characterize TPI, namely : minimum diameter limit for cutting, cutting cycle, number of residual trees, and diameter of residual trees (Dirjen Kehutanan, 1972). There are four basic assumptions in deciding these factors, those are annual diameter growth of $1 \mathrm{Cm}$, annual volume growth of $1 \mathrm{CuM}$ per $\mathrm{Ha}$., and cutting cycle 35 years. It is also assumed that the residual trees will grow to harvestable size during a cutting cycle.

The TPI system tries to balance current yield against future yield only in the measurement of physical volume, without considering the monetary value of current and future harvests. Therefore, if the TPI system is accepted as a tool in managing natural forest, it needs to be evaluated from financial or economic view.

One way of evaluating TPI system is by finding the optimal residual stocking and length of cutting cycle that maximizes discounted income stream. Chang (1981) stated that maximizing present value of income stream, which he called forest value, is the correct method for determining the optimal cutting cycle and growing stocks. He defined forest value as the expected discounted value of yield from the forest, which can be measured by the maximum present value of all future net refenues when the optimal cutting cycle and growing stocks were chosen. Numerous writers have justified the use of present value as the criterion for optimal forest value including McKean (1958), Bierman and Smidt (1966), and Hirsleifer (1958, 1970). In this paper the forest value is defined as the discounted value of royalties from the timber extracted from natural forest.

The primary objective of this study is to develop a steady-state harvesting model for managing natural forest. Steady-state management forces the harvest to be equal to the growth rate. This model will be used to examined the following policies :

1. The optimal cutting cycle

2. The optimal species and diameter distribution of residual stand

3. The optimal diameter distribution of tree harvested.

A secondary objective of this study is to examine the effect of the residual stand damage on discounted income stream and the optimal decision variables. Understanding this phenomenon will provide a better justification for enforcing regulations to control the damage to the residual stand during logging practices.

\section{LITERATURE OVERVIEW}

\section{A. Optimum Harvesting in Uneven-aged Stand}

Forest management for timber production can be classified into two main system : even-aged and uneven-aged management. Both system have their roots in the prin- ciples of silviculture, and are used to meet the objectives of forest management. The difference between these to system are perceptions, the relative weights for each objective, and the method for achieving the management goals (David and Johnson, 1987). Uneven-aged silviculture and management is the manipulation of forest for continuous high-forest cover, recurring regeneration of decirable species, and the orderly growth and development of trees through a range of age or diameter classes to provide a sustained yield of forest products.

Uneven-aged management emphasizes protection and enhancement of stable forest environment, and quality of timber produced. Hann and Bare (1979) mentioned that the objective and the weight given to every objective of forest management is mainly in maintaining health, stability of forest stands, and guaranteeing sustained yield. Proponents of uneven-aged management have claimed that these objectives can be achieved only by using unevenaged system. Therefore the basic problem is to identify the features of forest stands which are capable of producing the maximum sustained yield.

The concept of optimality in harvesting uneven-aged forest has been recognized for years. Attempts to establish the parameters of this kind of harvesting were made by several authors. Behre (1945) pointed out that for a given level of output, the required growing stock is a function of cutting cycle and may be expressed as a multiple of the yield.

The first relevent work of determining the rotation ages for timber stands is that of Martin Faustmann (1849). He found that the correct method for determing harvest age is to maximize the present value of infinite series of cash flow which emanate from the stand. Just as the management framework of an even-aged forest is built aroud the rotation, the management of uneven-aged forest is built arount the cutting cycle.

Mathews (1930) tried to provide direction toward developing allowable cuts and cutting cycles based on the assumption that uneven-aged stand are a composite of miniature even-aged stands. Therefore, yield table of evenaged stand can be used in predicting the yield from the uneven-aged stands. But Reynolds (1954) and Walker (1956) disputed Mathew's assumption and found out that the growth of trees in uneven-aged stand is different from the growth of trees in even-aged stands. They pointed out that competition in uneven-aged stands is mainly among different ages, while for even-aged stands, it is among the same ages, and this gives different effects on growth.

Based on the work of de Liocourt (1898), Mayer (1943, 1952) and Mayer at al (1961) provided diameter distribution guidelines, which can be used in managing uneven-aged forest. They mentioned that first numerical studies of growing stock distribution in uneven-aged stand was done by de Liocourt,which described as a geometric series wiht a parameter' of "q", and can be determined by dividing the number of trees per acre in a given diameter 
size class by the number of tress in the next larger diameter size class. An uneven-aged stand that can be described in such manner is said to be sustainable and to have balanced diameter distribution. Meyer (1952) used "q" largest residual tree diameter, residual stocking target, and current stand structure to predict future yields by projecting ingrowth in each size class over a certain period of time.

It must noted that de Liocourt's law was based on a balance diameter distribution. Therefore not all uneven-aged forest follow the reverse J-shaped distribution implied by this law (Mayer,1952; Leak, 1964; Adams and Ek, 1974). In developing an alternative approach, Leak (1964) conducted an extensive study of stand records from the Barlett Experimental Forest. He found out that the number of trees in successive 2 inches d.b.h. classes were not constant; and hence diameter distribution of the stand could not be accuralately described by the constant "q". He showed that the trend of the ratio between diameter frequencies "q" increased with diameter. The negative exponential function which impose a constant proportional decrease "q" implies that factors of ingrowth, growth, and mortality affect all size classes only in proportion to their frequencies.

Duerr and Bond (1952) were among the first to have used economic criteria for determination of stocking levels on uneven-aged stands. They mentioned that an optimal species mix, diameter distribution, and cutting cycles should be based on economic criteria. The optimal stocking was defined as the number of trees in growing stock that gives the maximum net return per unit of time. This can be attained by equating marginal value growth in percent to the alternative rate of return. Their model only defined the maximization conditions to optimize stocking volumes and neglected consideration of cutting cycle length and diameter distribution.

Mohd. Shahwahid (1985) determined the cutting regime of dipterocarp forests by using criteria of finansial maturity concept. He found that the optimal cutting limit for Dipterocarp forest is between 30 and $55 \mathrm{~cm} \mathrm{~d}$. b.h. depending on species. He used constant rate of growth increament for all species and diameter classes.

\section{B. Optimization System}

The optimization system used in univen-aged forest can be categorized into two main categories; namely static and dinamics optimization. In static optimization, the harvesting and the residual stocks are assumed to be equal for every cutting cycle, which implies that equilibrium is reached at the end of the first harvesting. In dynamic optimization, on the other hand,the harvest and residual stocks need not be equal for every harvesting until it reaches the equilibrium state.

The use of a static model is good only if the forest is already at fully stocked level. Therefore, one of the advan- tage of the dynamic optimization is to regulate forest in reaching its fully stock level after a period of time.

One of the most popular mathematical programming methods to solve thi optimization system is linear programming (LP), where the constraints and the objective are linear. Bare and Schreuder (1976) mentioned that the reason for the popularity of this technique is probably due to its simplicity of model formulation, computational capacity, minimal data requirements, and general level of managerial familiarity. Hann and Bare (1979) applied linear programming to uneven-aged forest, and identified two separate but related issues regarding level of harvesting and harvest scheduling. They determined the optimal sequence of diameter distribution, conversion strategy, and length of conversion period. In the United States, the National Forest Planners have used a LP called Forplan (Jhonson, et al. 1980) as the principal tool for resource allocation and activity scheduling. Forplan can simultaneously determine the future land use of each analysis area and optimally schedule management activities over a finite planning horizon.

Mendoza and Setyarso (1986) also used LP to find the optimal volume harvested and to test sustainability of The Indonesian Selective Cutting system (TPI). They found out that using the TPI requirements for managing Dipterocarp forest could not sustain future harvests. The result is based on volume harvested, with out any consideration on the financial/economic and species composition aspects.

Dynamic programming (DP) has not received as much attention in forest management as has LP. Cawrse (1979) said that, even if the dimensions of the system are only moderately large, the numerical solution of DP problems on the computer is prohibitive due to insufficient computer storage capacity. Haight et al. (1985) used DP procedure to determine the optimal sequence of diameter distributions and selection harvests for an existing stand by using the gradient method and starting with an initial guess of control variables.

Optimal control theory has been applied to stand level management problems, but results have either not been presented or have unstable and difficult to interpret. Adams and Ek (1974) depeloved a control theoretical formulation of a conversion strategy problem in which the control varibles were the number of trees to be cut per diamerter class in each period. Because both state and control variables were constrained to be non-negative, the development and execution of procedure was inpractical. When the control variables were changed to the percentage of tress cut per diameter class in each period and bounded between 0.0 and 1.0 (Adams and Ek, 1975), no constraint was needed on state variables. No solution procedure was presented, however.

Rapera (1980) formulated the optimal control of Adams and Ek (1974) and tested three solution procedure. He used the stand growth simulator given by Adams and Ek (1974) to model diameter class growth dynamics, using 
stumpage value function that assigned premiums to large diameter trees. He found out that the two procedures which used the gradient based control-vector iteration method (McDonoungh and Park, 1975) converged to solutions within specified tolerances. However values of optimal solutions varied by more than 25 percent depending on different initial values given to control variables. Harvest patterns ranged from periodic removal of all trees greater than 6 inches to the maintenance of a downward-sloping residual diameter distribution with a maximum tree size of 20 inches. He concluded that many locally optimal solutions existed.

Haight et al (1985) formulated the optimal control and solved it by using a multi dimensial version of the method of steepest descent used by Dreyfus and Law (1977) to numerically solve single variable discrete-time optimal control problems. The method of steepest-descent is a gradient based method which finds solutions by setting first derivatives equal to zero, which are neccessary conditions for any relative maximum or for any other types of statationary solutions. From this, they concluded that they can never know which one the global optimum is.

\section{Growth Model}

Several methods has been developed to project the evolution of uneven-aged foret stands. These can be categorized in two broad groups according to whether the unit considered by the model is a tree or a stand.

Single tree models such as those developed by Botkin et al (1972),Ek and Monserud (1974), and Schugart and West (1977) have proved to be very powerful means of representing competition between trees, variation in species composition, and environmental influences on forest growth. This model is necessary if quality is an important objective of the model, but it needs detailed information.

Whole stand models, though, are by nature much more aggregated, representing forest stand with very few parameters. Neverthelees, the amount of information they provide is usually sufficient to answer key importance questions of the forest managers (Davis and Johnson, 1987). One of the oldest whole stand model used to predict uneven-aged forest growth is the stand table projection (Husch et al, 1982), but more compact models have since been devised by Moser (1967), Leary (1974), and Leak and Graber (1976).

Comparisons of forecasting performances of a wholestand model against those of a single-tree distance dependent model done by Ek and Monserud (1979) have shown that the former forcast almost as well and more cheaply. These whole stand model, coupled with optimization techniques, have parmitted the analysis of management alternatives (Adams and Ek, 1974; 1975; Adams, 1976 ). For these reasons, the models have the potensial of becoming practical forest management tools.

One of the stand models is matrix model which is based on Leslie's growth model (Leslie,1945 and 1948), which originally designed to investigate the effect of age structures of female on the growth of animal populations. Bosh (1971) applied Leslie's model to analyze the growth of California redwoods, and Wadsworth (1977) used it to predict the growth of tropical forest.

\section{MODEL FORMULATION}

\section{A. General Model}

Since land and growing stock are the factors that determine the productivity of uneven aged forest, these factors must be include in the optimization of the production system. In this study land is assumed to be constant over time and therefore can be left out of the analysis, the problem then is to find the optimal number of trees harvested as well as the number of residual growing trees as to maximize the discounted income stream for a given length of cutting cycle (t), discount rate (r), and residual stocks (s). This can be formulated in mathematical form as:

$$
\begin{aligned}
& \text { Max. W } \left.=\sum_{k}^{\infty} \sum_{j=1}^{2} \sum_{1=1}^{7} H_{i j k}\left(P_{i j k} /((1+r)(k t))-1\right) \ldots \ldots \ldots .1\right) \\
& \text { Subject to : } \\
& X_{\mathrm{ijk}}=\mathrm{g}_{\mathrm{t}}\left(\mathrm{t}, \mathrm{S}_{\mathrm{ijk}}\right) \\
& X_{i j k}-H i j k=S_{i j k} \ldots \ldots \ldots \ldots \ldots \ldots \ldots \ldots \ldots
\end{aligned}
$$

Where :

$\mathrm{W}=$ discounted income stream $(\$ / \mathrm{ha})$

$\mathrm{P}_{\mathrm{ijk}}=$ stumpage prices $(\$ /$ tree $)$ of tree species $\mathrm{j}$ and class diameter of 1 in period $\mathrm{k}$

$\mathrm{X}_{\mathrm{ijk}}=$ number of trees of diameter class $\mathrm{i}$ and tree species $\mathrm{j}$ immediatedy before harvest in period $\mathrm{k}$

$\mathrm{S}_{\mathrm{ijk}}=$ number of tree species $\mathrm{j}$ and diameter class $\mathrm{i}$ in period $\mathrm{k}$

$\mathrm{H}_{\mathrm{ijk}}=$ number of tree harvested of tree species $\mathrm{j}$ and diameter class $\mathbf{i}$ in period $\mathbf{k}$

$\mathrm{g}_{\mathrm{t}}=$ transition matrix for $\mathrm{t}$ year cutting cycle

The objective function, equation 1) is formulated to seek value of decision variables that maximize the present net worth (W) of financial retuns from harvesting in perpetuity. No restriction is placed on the form of the final disrtibution. Equation 2) represent the stand growth dynamic constraints fot $t$ years cycle, as the number of trees before harvested in period $k+1$ is equal of residua! stand of sijk after $t$ years of growing.

\section{B. Steady State Assumptions}

The natural forest is endowed to a nation of all generations as an asset.Present generation should not harvest the capital but the rent, so that it benefits not only present 
generation but also future generations. The rent from the natural forest is equal to the total growth as result of letting residual stock to grow for a length of cutting cycle. Ortiz-Crespo (1989) defined sustainablity as the ability to live off the interest and not the capital of natural resources.

A managed uneven-aged forest is in a steady-state when the harvest is just equal to the natural rate of growth for all species and diameter classes. The survival of tropical forest depends particularly on developing sustainable yield management. Therefore, in a given length of cutting cycle, number of residual trees, and number of trees immediately before harvest are equal for every period of harvesting or $\mathrm{H}_{\mathrm{ijk}}=\mathrm{H}_{\mathrm{ijk}+1}, \mathrm{~S}_{\mathrm{ijk}}=\mathrm{S}_{\mathrm{ijk}+1}$, and $\mathrm{X}_{\mathrm{ijk}}=\mathrm{X}_{\mathrm{ijk}+1}$. With the steady - state assumption, the model can be simplified as:

$$
\begin{aligned}
\operatorname{Max} . W & =\sum_{\mathrm{j}=1}^{2} \sum_{1=1}^{7} \mathrm{H}_{\mathrm{ij}}\left(\mathrm{P}_{\mathrm{ij}} /(1+\mathrm{r})^{(k \mathrm{t})}-1\right) \\
& =\sum_{\mathrm{j}=1}^{2} \sum_{\mathrm{t}=1}^{7} \mathrm{H}_{\mathrm{ij}}\left(\mathrm{P}_{\mathrm{ij}} /\left((1+\mathrm{r})^{\mathrm{t}}-1\right) .\right.
\end{aligned}
$$

Subject to :

$$
\begin{aligned}
& H_{i j}=X_{i j}-S_{i j} \\
& X_{i j}=g_{t}\left(t, S_{i j}\right)
\end{aligned}
$$

The objective function, equation 5), can be further simplified so that it can be solved by linear programming, that is by calculating the stumpage price as present net worth of royalties in perpetuity $\left(\mathrm{Stv}_{\mathrm{ij}}\right)$. In mathematical form this can be shown as :

$$
S t v_{i j}=P_{i j} /\left((1+r)^{t}-1\right)
$$

and the model becomes :

$$
\begin{aligned}
& \text { Max. W }=\sum_{j=1}^{2} \sum_{1=1}^{7} S_{i j} H_{i j} \\
& \text { Subject to : } \\
& \mathrm{H}_{\mathrm{ij}}=\mathrm{X}_{\mathrm{ii}}-\mathrm{S}_{\mathrm{ij}} \\
& X_{i j}=g_{t}\left(t, S_{i j}\right)
\end{aligned}
$$

\section{Damage to the Residual Stand}

The contraints, equation 6), which ensure the impossibility of harvesting nonexisting-tree, also ensure that the total number of trees harvested and the number of trees left as residual trees is equal to the total number of trees before harvested. In reality, this condition is unlikely to occur since some damages in selective logging can not be avoided. Some of the trees were damaged during the harvest.

The success of the selective cutting system depends on the satisfatory retention of undamaged residual trees over a range of size classes, which when released will be able to grow to felling size during the next cutting cycle.Damage to the residual stand can not be neglected, but it should be minimized. This fact must be included in the model. If the allowance for residual damage is $d$; then the constraint equation 6) becomes:

$$
\begin{aligned}
& X_{i j}-H_{i j}-d\left(X_{i j}-H_{i j}\right)=S_{i j} \\
& \text { or } \\
& \left(X_{i j}-H_{i j}\right)(1-d)=S_{i j} \\
& \text { or } \\
& X_{i j}-H_{i j}=S_{i j} /(1-d) \ldots \ldots \ldots
\end{aligned}
$$

\section{Growth}

Growth is one important factor that affects the levels which decision variables can reac. Stand growth is measured as the change in a stand over some specified time. They can be specified on a period basis or for any combination of periods that which the users desire. The form of this constraint (equation 7) is not linear, and can be linearized by using transition matrix as follows:

$$
\mathrm{X}=\mathrm{GS}+\mathrm{C}
$$

In this constraint the matrix $\mathrm{G}$ and vector $\mathrm{C}$ should be compatible with the length of cutting cycle chosen. Therefore the value of matrix $G$ and vector $C$ vary with the length of cutting cycle, and should be computed as a multiple of the time unit in the basic growth model. The element of transition growth matrix is calculated from $p$ years continuous inventory and is given in matrix $\mathrm{Gp}$ and vector Cp. The residual stand should be grown for a cutting cycle length $(t)$ is equal to $c$ times $p$, where $c$ is cardinal number. It is assumed growth in the $p$ years is constant for each period of $c$. The transition growth matrix for $t$ years cutting cycle can be computed by the equation:

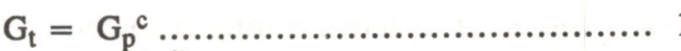

$$
\begin{aligned}
& C_{t}=\left(G_{p}(c-1) C_{p}\right)
\end{aligned}
$$

where $c$ is number of period of $p$ years, and $c$ times $p$ equals to the cutting cycle length of $t$ years.

Knowing the growth model and the allowance for residual damage the optimization model for uneven-aged forest becomes:

$$
\begin{aligned}
\text { Max. } W & =\sum_{j=1}^{2} \sum_{\mathrm{I}=1}^{7} S_{t v} H_{i j} \\
\text { Subject to } & : \\
H_{i j} & =X_{i j}-S_{i j} /(1-d) \\
X_{i j} & =G^{t} S_{i j}+C_{t} \ldots . .
\end{aligned}
$$

Since the objective function and constrains of this study 
are linear form for a given cutting cycle, linear programing is an appropriate tool to solve this optimization problem that could find simultaneously the steady state of $\mathrm{X}_{\mathrm{ij}}, \mathrm{H}_{\mathrm{ij}}$, and $\mathrm{S}_{\mathrm{ij}}$ for a certain length of cutting cycle, royalty, dicount rate, and allowance for residual damage. Despite its limitations, linear programming is a very powerful method because it has already had standard computer programs which are capable of findings optimal solutions if one exists (Buongiorno and Gilles, 1987; and Duloy and Norton, 1975).

Two aims are accomplished from the solultion of the linear programming; it specifies the level at which the activities must be operated to optimize the value of the objective, and it generates the shadow prices for each constraint.

\section{Required Data and Assumptions.}

Estimating growth is a critical element in building this optimization model. Continuous inventory on permanent plots with periodic remeasurements (in this paper every $p$ years) is the main data needed. This data provides the number of trees that die, that stay in the same diameter class, that grow to the next higher diameter class, and the ingrowth to the lowest diameter class over the $p$ years period for each species and diameter class.

In addition to growth information, economic data as timber price, timber harvesting cost, and discount rate, is needed. In the case of timber sold as standing trees, timber price and harvesting cost can be replaced by stumpage price or royalties, as prescribed by the Indonesian forest regulation, where royalty should be better if it was determined by the log market price and harvesting cost.

\section{IV.SIMULATION RESULTS AND DISCUSSION}

\section{A. General Remarks}

The purpose of selective cutting is to conserve the forest by leaving enough trees of different size classes which will grow into harvestable size during a predetermined period and shall give yield of approximately equal to or greater in volume than the previous timber harvested. This is in agreement with Kenneddy's (1985) definition of forestry as the management of forest resources to provide a satisfactory amount and mix of social values for people, while protecting the values and use options for future generations. However, the success of the selective cutting would depend on certain factors, among them are growth and mortality rates, logging damage, edequacy of residual stockings, and economic variables.

One of characteristic forest economics is the intertemporal choice or allocation of resources for consumptive and productive use over time. In forest economics, the classical economic problem is to determine when the stand should be cut and by how much. Therefore the problem of economic of natural forest is to determine the optimal rate at which natural forest should be cut.

A sensitivity analysis was performed in lieu of comparative static analisis to examine the responces of the choice variables by changing the economic parameters. Economic parameters such as discount rate and stumpage value or royalty. In this study is used 5, 7,5, and 10 per cent discount rate, and 5 regimes of royalty. Regime 0,1 , and 2 assume a $\$ 10$ royalty for dipterocarp combined with $\$ 0, \$ 5$, and $\$ 7.5$ per M3 royalty for non-difterocarp respectively. Regime 3 and 4 assume $\$ 15$ royalty for dipterocarp and $\$ 5$ and $\$ 10$ per M3 for non-dipterocarp respectively. Wagner (1969) states that sensitivity analysis of the objective function investigates the changes in the optimal solution, as the coefficients in the objective function are altered. Linear programming was used to find the optimal solutions, while the economic parameters and residual damages were systematically varied.

\section{B. Optimal Harvesting}

Selective cutting as a timber harvesting and timber production system is a time dependent activity, which is influenced by its environment and policies. The success of selective cutting would depend on the number of trees harvested, the number of trees left as a residual stand, and the time interval between two hervests, or cutting cycle. The problem in optimal intertemporal allocation of a biologically renewable-resource is to determine the level of current utilization and residual stocks.

Tabel 1 gives the result of simulation at different rates of residual damage at 5 percent discount rate. The optimum forest value occurs in the same cutting cycle for all regimes but varies according to residual damage. The change in the timber price which is shown by moving from one regime to other regimes does not affect the optimum cutting cycle, but the larger the residual damage is, the longer the cutting cycle; and the larger the discount rate is, the shorter the cutting cycle.

It seems that the length of cutting cycle is most affected by the discount rate. The purpose- of discounting is to reflect the opportunity cost of postponing consumption, which is represented by the "floor" of the relevant discount rate distribution, denominated by deposits in banks in real terms. The Forest Service of the USA justified a 4 percent discount rate in evaluating forestry projects. The floor of relevant discount rate distribution for forestry projects in Indonesia is probably around 5 percent. Hence, using 5 percent discount rate. for evaluating forestry activities is reasonable. At this rate the optimal cutting cycle varies between 35 and 45 years by the allowance of residual damage (see Table 1.). If residual damage can be reduced to less than 30 percent the 35 years cutting cycle as was embodied by the TPI system can be used as the optimal cutting cycle as long as the time 
preference of the society is $\mathbf{5}$ percent.

One of the major shifts in managing the tropical forest for the coming year is the increase of the utilization of species and size of trees. But even where a major part of the tree species is non commercial as in regime 0 , the cutting cycle that gives the maximum forest value is equal to the regimes where all trees are commercial as shown by regime 4 (Table 1 ).

The number of trees harvested for each species and diameter class is determined by cutting cycle, residual damage, and marketable species. It is rare for more than 25 to 30 percent of the standing volume of tropical mixed forest to be removed, and considerably less is actually utilized (Masson, (1983). The optimal number of trees harvested is shown in Appendix 1 and Appendix 2. For a cutting cycle of 30 years or higher, the number of trees harvested is equal for all regimess, but regime 0 . This means that the increase in royalties is not affecting the optimal number of tree harvested, except the change of noncommercial to commercial trees or from regime 0 to the other regimes.

Table 1. Forest value at various cutting cycles, residual damages and regimes (USS/Ha.)

Tabel 1. Nilai hutan pada berbagai rotasi tebang, kerusakan tegakan tinggal dan regime

\begin{tabular}{|c|c|c|c|c|c|}
\hline $\begin{array}{l}\text { Cutting cycle } \\
\text { (rotasi tebang) }\end{array}$ & $\begin{array}{c}\text { Regime } \\
0\end{array}$ & $\begin{array}{c}\text { Regime } \\
1\end{array}$ & $\begin{array}{l}\text { Regime } \\
2\end{array}$ & $\begin{array}{c}\text { Regime } \\
3\end{array}$ & $\begin{array}{c}\text { Regime } \\
4\end{array}$ \\
\hline & \multicolumn{5}{|c|}{20 percent residue damage } \\
\hline 15 & 165.71 & 205.27 & 231.40 & 283.66 & 333.89 \\
\hline 20 & 207.87 & 220.21 & 273.75 & 321.93 & 371.94 \\
\hline 25 & 230.52 & 275.94 & 303.58 & 386.40 & 441.62 \\
\hline $30 *$ & 232.55 & 278.87 & 307.93 & 389.37 & 447.44 \\
\hline $35 *$ & 238.46 & 283.60 & 313.06 & 396.30 & 454.91 \\
\hline 40 & 230.22 & 273.30 & 301.83 & 381.63 & 438.57 \\
\hline \multirow[t]{2}{*}{45} & 205.24 & 244.77 & 268.67 & 343.98 & 391.26 \\
\hline & \multicolumn{5}{|c|}{30 percent residue damage } \\
\hline 15 & 107.82 & 140.68 & 161.49 & 191.86 & 231.88 \\
\hline 20 & 126.17 & 159.94 & 181.09 & 218.80 & 260.99 \\
\hline 25 & 149.49 & 181.27 & 201.93 & 252.58 & 292.16 \\
\hline 30 & 161.34 & 191.56 & 213.45 & 273.01 & 310.86 \\
\hline $35 *$ & 173.19 & 208.00 & 228.25 & 291.66 & 332.21 \\
\hline $40 *$ & 173.56 & 208.24 & 228.92 & 291.84 & 333.12 \\
\hline \multirow[t]{2}{*}{45} & 161.92 & 193.47 & 211.21 & 272.46 & 308.02 \\
\hline & \multicolumn{5}{|c|}{40 percent residue damage } \\
\hline 15 & 80.83 & 109.25 & 125.54 & 147.60 & 180.08 \\
\hline 20 & 93.73 & 123.08 & 141.44 & 166.78 & 202.98 \\
\hline 25 & 103.44 & 131.96 & 149.80 & 180.91 & 215.59 \\
\hline 30 & 112.72 & 136.63 & 156.72 & 192.57 & 226.54 \\
\hline 35 & 123.82 & 149.11 & 165.01 & 209.13 & 239.62 \\
\hline $40 *$ & 127.98 & 153.85 & 168.55 & 216.47 & 245.29 \\
\hline $45^{*}$ & 124.84 & 149.59 & 166.40 & 210.20 & 239.77 \\
\hline
\end{tabular}

*: Optimal forest value between these two cutting cycle

(Nilai hutan optimum diantara dua rotasi tebang ini)

The minimum diameter tree as prescribed by the TPI is lower than the lowest diamter harvested by the model. The lowest diameter harvested by the model is $70 \mathrm{Cm}$ for 20 and 30 percent residual damage, and $60 \mathrm{Cm}$ for dipterocarp and $50 \mathrm{Cm}$ for non-dipterocarp at 40 percent residual damage; while the TPI prescribes $50 \mathrm{Cm}$ for both species. In practice the lower limit is agree to the result of the simulation, since the loggers usually choose larger trees which have more volume.

The model is used to simulate three diameter limits namely $50 \mathrm{Cm}, 60 \mathrm{Cm}$, and $70 \mathrm{Cm}$ for three periods of harvesting (Appendix 3). The limit diameter of $50 \mathrm{Cm}$ showed that volume harvested was decreasing from the first harvest to the third harvest. The limit diameter of 60 $\mathrm{Cm}$ showed that volume harkested is decrease from the first to the second harvest, and then increased to the third harvest. While $70 \mathrm{Cm}$ limit the volume harvested is increased from the first harvest through the third harvest. Therefore, in order to perpetuate the timber production, the diameter limit for cutting should be reconsidered by using larger than $50 \mathrm{Cm}$.

The method determining optimum stocking is simple in concept, but its application to specific forest stands may be difficult, due to the scarcity of reiable information on timber growth as related to stand characteristics, and timber value as related to density and size. The general principle of optimum stocking occurs when marginal cost of additional stocking is equal to its marginal revenue. Residual inventory refers to the physical examination of marked residual trees left immediately after logging, which is very important in determining the condition of residual trees. The healthy trees left become the basis for predicting the yield in the succeeding cutting cycle.

The model simulated the optimum number of healthy residual trees for various cutting cycle length and regimes (Appendix 5). The results of the simulation shows that the allowance for residual damage has an effect on the optimal residual stock not only in the number but also in the class diameter limit. The higher the allowance for residual damage, the smaller the number and the maximum diameter of residual stock. At 30 percent allowance for residual damage or less, the optimum residual trees is greater than residual stocking required by the TPI, but at 40 percent allowance for residual damage, the optimum residual stocking is less than residual socking prescribed by the TPI. It appears that the existing standard of residual trees prescribed by the TPI needs to be reviewed in order to get the optimal forest value.

The optimal number of residual trees for a 30 years cutting cycle and longer is equal for all regimes. This means thar an increase in timber price or decrease in cost of harvesting which are reflected in the increase in royalty do not affect the optimal residual stock. In a steady-state forest the optimal number of residual stock in a remote area is just the same as the number of residual stock in an accessible area if both areas have the same growth rate.

\section{Effects of Change in Economic Parameters.}

In addition to the optimal levels of the choice varables, some questions that foresters in managing natural forest may have concerned the impact of expected changes in the economic parameters on the optimal level. In other words, 
if real price, cost and discount rate should change, what are the directions and magnitudes of changes in the forest value and the choice variables. The purpose of comparative static analysis on a general model is to determine the direction of the movements on the optimal level of choice variable, given a change in a single economic parameter. The result of the analysis should hold in all cases where the model is applicable.

The change of preference for future consumption to presence consumption is reflected in discount rate changes. If the value of consumption today is higher than the value of consumption tomorrow, then the discount rate is higher. On the other hand if the value of consumption today is lower than the value of consumption tomorrow, then discount rates should be lower.

Increase in timber price or decrease in cost of harvesting should be reflected by an increase in royalties, and viceversa. The change in royalties can be seen as a movement from one regime to another regime.

Table 2. Forest value (US\$/Ha) at various cutting cycles, discount rates and regimes at $30 \%$ residual damage

Tabel 2. Nilai hutan pada berbagai rotasi tebang, suku bunga dan regime bila kerusakan tegakan tinggal $30 \%$.

\begin{tabular}{|c|c|c|c|c|c|}
\hline $\begin{array}{l}\text { Cutting cycle } \\
\text { (rotasi tebang) }\end{array}$ & $\begin{array}{c}\text { Regime } \\
1\end{array}$ & $\begin{array}{l}\text { Regime } \\
2\end{array}$ & $\begin{array}{l}\text { Regime } \\
3\end{array}$ & $\begin{array}{l}\text { Regime } \\
4\end{array}$ & $\underset{5}{\text { Regime }}$ \\
\hline \multicolumn{6}{|c|}{5 percent discount rate } \\
\hline 15 & 140.68 & 161.49 & 191.86 & 231.88 & 235.85 \\
\hline 20 & 159.94 & 180.98 & 218.80 & 260.99 & 290.63 \\
\hline 25 & 181.33 & 202.01 & 252.62 & 292.99 & 375.48 \\
\hline 30 & 194.56 & 213.45 & 273.01 & 310.86 & 408.19 \\
\hline 35 & 208,00 & 228.25 & 291.66 & 332.21 & 436.28 \\
\hline 40 & $208.24 *)$ & $228.92 *)$ & $291.84 *)$ & $333.12 *)$ & $437.31 *)$ \\
\hline 45 & 193.47 & 211.21 & 272.21 & 308.02 & 404.67 \\
\hline \multicolumn{6}{|c|}{7.5 percent discount rate } \\
\hline 15 & 77.53 & 88.86 & 105.68 & 127.75 & 123.30 \\
\hline 20 & 81.36 & 92.14 & 111.31 & 132.88 & 147.93 \\
\hline 25 & $84.90 *)$ & $94.59 *)$ & $118.23 *)$ & $136.81 *)$ & $175.70 *)$ \\
\hline 30 & 83.34 & 91.62 & 116.97 & 133.18 & 174.79 \\
\hline 35 & 81.15 & 89.05 & 113.88 & 129.68 & 170.21 \\
\hline 40 & 73.89 & 81.19 & 103.38 & 117.99 & 154.93 \\
\hline 45 & 62.06 & 67.72 & 87.44 & 98.73 & 129.70 \\
\hline \multicolumn{6}{|c|}{10 percent discount rate } \\
\hline 5 & 31.48 & 37.20 & 41.39 & 52.91 & 30.40 \\
\hline 10 & $51.25 *)$ & $60.86 *)$ & $67.27 *)$ & $86.48 *)$ & 77.60 \\
\hline 15 & 47.84 & 54.83 & 65.12 & 78.79 & 78.04 \\
\hline 20 & 46.17 & 52.22 & 63.13 & 75.34 & 81.91 \\
\hline 25 & 44.01 & 49.07 & 61.28 & 70.89 & $91.10 *)$ \\
\hline 30 & 39.23 & 43.10 & 55.11 & 62.64 & 82.46 \\
\hline 35 & 28.31 & 31.19 & 39.82 & 45.49 & 59.64 \\
\hline 40 & 28.31 & 31.19 & 39.82 & 45.49 & 59.64 \\
\hline
\end{tabular}

Tabel 2 gives the forest value for 5, 7.5, and 10 percent discount rate. There is no doubt that the higher the discount rate, the lower the forest value, but more important is the change in the length of cutting cycle which gives the maximum forest value as a result of change in discount rate. Increasing discount rate by 2.5 percent will decrease the length of cutting cycle by. approximately 15 years, that is, from around 40 years at 5 percent to 25 years at 7.5 percent, and to 10 years at 10 percent discount rate for all regimes, except for regime 5 at 10 percent discount rate. Unlike the other regimes which assume constant price over diameter, regime 5 places higher value on larger diameter trees, and at 10 percent discount rate the length of cutting cycle that gives the maximum forest value is 25 years, which shows that by valuing higher price for larger trees will lengthen the cutting cycle.

Changing in timber price or decrease in cost of harvesting is reflected as a change in royalty. There is no doubt about the increase of forest value as the royalty increase, but more interesting is that the change in royalties does not affect the choice variables as cutting cycle length, number of tree harvested, and number of residual trees. For the same alowance of residual damage and discount rate, the optimal choice variables that gives the maximum forest value are equal for all regimes. Therefore, the supply of timber from $1 \mathrm{Ha}$. of forest is price inelastic.

One of the most controversial concept in forest management has been, and to some extent still is, the validity of compound interest and the appropriate rate to apply when necessary. There is little evidence that compound interest considerations have had much influence in forestry practice on the major decision taken. Solow (1974), for instance, tends towards zero interest to implicate Ramsey's argument : that it is ethically indepensible for society to discount future utility. Peterson (1977) quoted Eckstein who mentioned that discount rate which gives priority to present consumption, is not a fair allocation of the resoures for unborn generations.

\section{Policy Implication of the Simulation}

The simulation shows that the selective cutting system which is practiced almost everywhere in mixed tropical forest is still the best choice in managing natural dipterocard forest. For selective cutting, there are three choice variable which affet the optimum result of managing uneven-aged deperocarp fprest: 1) length of cutting cycle, 2) harvesting level, and 3 ) residual level. The length of the cutting cycle is affected by discount rate and the allowance for residual damage, while the level of harvesting and residual stock are affected by the length of cutting cycle.

The use of unjustifiable discount rate would cause inefficiencies and misallocation of resources. There are certainly some who feel that any discounting of future consumption must be at a relatively low rate, especcially as a way of justifying sustainable management in forestry. But most economist argue that using a low discount rate would cause an over-value of future wants or future allocations. On the other hand high discount rate means an over-value of present wants or present allocations. Low and high discount rate is a relative value; to some a certain discount rate is low, but to other that figure is high. 
Eventhough the effect of residual damage is not as important as discount rate, the residual damage does affect the optimal management of uneven-aged stands. As was mentioned earlier, incidence of damage affects the choice of suitable length of cutting cycle, where the degree of residual damage, the higher the forest value is. Therefore, the damage to the residual stand must be kept as low as possible, as long as the cost of minimizing the damage is less than the increase in forest value, in order to mintain the forest as a perpetual supplier of merchantable trees. Dawkins (1968) pointed out that felling damage depends more on the number of trees felled than on the volume removed. Hence, raising the diameter limit of tree for harvesting may greatiy reduce the potential damage, while having only a small effect on the volume extracted. The diameter limit of $50 \mathrm{~cm}$ as prescribed by TPI could be raised to $70 \mathrm{Cm}$, not only to get the optimum diameter for harvesting but also to reduce residuls damage.

The justifiable choice of these two factors would lead to the best choice of cutting cycle that gives the optimal forest value. In each cutting cycle there are two optimum choice variables, those are: number of tree harvested, and number of tree left as a healthy residual stand. But the rate of self-renewal is partly dependent on the size and distribution of the residual stock, not on the number of tree harvested. Therefore the basis of the selective cutting management should not only be on the number of tree harvested or diameter limit but also on an adequate number of trees in each species and diameter classes. By using the minimum diameter as a requirement for seiective management, forest stocking can never be improved and an understocking is always understocked. Trimble (1971) recommended not to favour any concept of managing by control of diameter limit alone, since it is usually difficult to engage in silvicultural tasks, and because continual diameter limit carries long-term disadvantage.

In deciding the most approriate choice variables, it is better to use the optimal residual stand. By using this method instead of diameter limit only, selective cutting management works toward forest improvement. If the number of trees before harvest is lees than optimal residual trees then harvesting is postponed. On the other hand, all in excess of the optimal residual trees should be harvested.

Therefore the objective of selective cutting is to conserve the forest by leaving optimum healthy residual trees of different species and diameter classes in perpetuity, in order to maximize the forest value at predetermined periods. This involves at least two principal phases, namely tree marking and residual inventory, and is even better if combined with timber stand improvement.

Tree marking is done to ensure that the number of trees for future crops is optimal, and will be protected from logging damage. In other words, tree marking should guide the loggers in deciding which trees to be cut, the planning of skid trails, and direction of felling.

Residual inventory is done to count and examine the marked healthy residual trees which are left after logging. It is a form of evluation of the effectiveness of timber licensing; whether it works properly in avoiding damage to marked trees. Residual inventory also detemines the condition, size, and the number of healthy residual trees as a basis for timber stand improvement planning. The royalties should be paid not only for the tree removed, but also for all trees damaged in order to minimize the cost to the society.

Timber stand improvement is a post-logging phase of the system. Its purpose is to improve the growth, quality, and composition of growing residual stock. In Malaysia and Philippine, this phase consists of two stages; namely refining and liberation. Refining involves cutting of climbers and girdling of mature non-ccmmercial trees and other badly shaped or defective trees; while liberation involves eliminating competition from inferior trees.

The simulations also show that royalties do not directly affect the optimal cutting cycle. On the other hand, change in residual damages does affects the optimal variables. Gillis (1988) pointed out that royalty system in tropical forest causes severe damage to residual trees, especially when the royalties paid are based on volume removed. He further affirmed that flat rate income taxes and differentiated royalties are far superior to either uniform royalties or advalorem royalties, but require detailed data or information which is difficult to obtain in develoving countries. Therefore, research is needed to determine which royalty system recovers most for rent while discouraging damage to residual trees, yet without requiring additional and costly detailed information.

\section{CONCLUSIONS AND RECOMMENDATIONS}

\section{A. Conclusions}

The model presented in this study provides a general solutions procedure for determining optimal levels of decision variables facing managers of uneven-aged dipterocarp forest, regarding choice variables of cutting cycle, number of tree harvested, and number of residual trees.

The application of linear programming to solve the model has an advantage of determining maximum forest value and at the same time gives the optimal allocation for reaching the objective. Therefore it can be used as a tool to provide alternatives in the management of tropical forests.

Experimentation with the model indicates that changes in economic parameters do effects the forest value. The discount rate affects the forest value as well as the choice variables. Discount rate, which can be used as an economic parameter but also as a choice variable that measures time preference, has a significant effect on the optimum management through the length of the cutting cycle that gives maximum forest value. The lower the 
discount rate is, the longer the cutting cycle and ultimately the lagger the number of tree harvested and left as a residual stocking.

One other interesting out come of the experimentation was the revelation of an insensitivity of the optimal management to change in royalty as a change in cost of harvesting or delivered price. The change in the harvesting cost or delivered log price which are incorporated in the change in royalty does not change the optimal variables. This finding enables managers to establish the optimal choice of variables without worrying about the market situation, for instance, the location of the forest in respect to the market.

A manager of uneven-aged stands would not have to make major change in long term management to plans due to changes in market price. The forest managers could simply maintain the long term plan and examine the sorth run market price to determine the acreage for harvesting.

Regardless of its weakness, selective cutting (TPI) is still a usefull tool in managing dipterocarp forest, but it could be improved with some modifications in diameter limit, residual stock, and especially the allowance for residual damage which was not prescribed in the TPI.

\section{B. Recommendations}

The growth of trees in one of the most important aspect of species differences in determining of forest composition and management. Many important timber species appear to have need relatively open conditions for maximum growth which can be provided by TPI, but this has rarely quatified. The transition growth matrix which performed well in this model could be developed to incorporate more species and diameter classes. Experimentation of this growth model into more sample plots and longer periods of observation would help in untherstanding the performance of tropical forests.

The success of selective logging depends on the survival of an adequate number of healthy residual trees. Therefore, careful logging practice is required, and further study is needed to find the minimal residaul damage that can be reached technically while remaining sound economically.

Determination of harvesting cost in terms of location and tree variables such as diameter and species, is critical in finding the best royalty system, so that it captures a major share of potential timber rent, while achieving its intented of encouraging increased utilization of species and $\log$ sizes, as well as discouraging damage to residual growing stocks.

\section{BIBLIOGRAPHY}

Adams, D. M. 1976. A note on the interdependence of stand structure and best stocking in a selection forest. Forest science 22(2):1980-1984.
Adams, D.M. and A.R. Ek. 1974. Optimizating the management of uneven-aged forest stands. Canadian J. of For. Research 4 : 274-287.

Alder, D. 1980 . Forest volume estimation and yield prediction. Vol. 2. Prediction. FAO Forestry Paper 22/2. Rome. 194 p.

Arbogast, C. Jr. 1957. Marking guides for Northern hardwoods under selection system. USDA For. Service, Lake State For. Exp. Station. Station Paper 56. 20 pp.

Bare, B. B. and G. F. Schreuder. 1976. Applications of system analysis in wildland management : an overview. Paper presentedat ORSA/TIMS Joint National Meeting. Philadelphia, Pensylvania, March 31- April 2, 1976.

Behre, C. E. 1945. Growing stock, cutting age, and sustained yield. J. of Forestry $43: 447-483$.

Bickford, C. A. 1957. Stocking normality and measurement of stand density. J. of Forestry 55 : 99-104.

Bierman, H. and S. Smidt. 1966. The capital budgeting decision. New York.

Bosch, C. A. 1971. Redwoods : a population model. Science 172 : 345-349.

Buongiorno, J. and J. K. Gilles, 1987. Forest Management and Economics. A rimer quantitative methods. Macmillan Publishers, New York. 285 pp.

Cawrse, O. C. 1979. Dynamic system modelling in timber management : a selected annotated bibliography. Dept. of For. and Wood Resources, Colorado State Univ. Fort Collins, Colorado. 20 pp.

Chang, S. J. 1981. Determination of the optimal growing stock and cutting cycle for uneven-aged stand. Forest Science 27 (4) : 739-744.

Davis, K. P. 1956. Detemination of desirable growing stock a central problem of forest management. J. of Forestry 54 : 811-815.

Davis, L. S. and K. and. Johnson. 1987. Forest Management. 3rd Ed. McGraw-Hill Book Co. New York. $790 \mathrm{pp}$.

Dirjen Kehutanan, 1972. Surat keputusan Dirjen Kehutanan No. 35/KPTS/DP/I/72 tentang Tebang Pilih Indonesia, Tebang Habis dengan Penanaman, dan Tebang Habis dengan Permudaan Alam. Jakarta.

Dreyfus, S.E. and A.M. Law. 1977. The art and theory of dynamic programming. Academic Press, New York. $283 \mathrm{pp}$.

Duer, W.A. and W.E. Bond. 1952. Optimum stocking of a selection forest. J. of Forestry $50: 12-16$.

Duloy, J.H. and R.D. Norton. 1975. Price and incomes in linear programming models. American J. of Agric. Economics 57(4): 591-600.

Ek, A.R. 1974. Nonlinear model for stand table projection in northen hardwood stands. Canadian J. of For. Research 4 : 23 - 27. 
Ek, A.R. and R.A. Monserud. 1974. Trials with program FOREST : growth and reproduction simulation for mixed species even or uneven-aged stand. In: Growth model for tree and stand simulation. Fries, J. (Ed.) Dep. Yield Res. Coll. Forestry. Stockholm. Research Note 30 : 56-73.

Goodspeed, A.W. 1945. Determination of the regulated empirical growing stock from field data. J. of Forestry 43 : 908-914.

Haight, R.G., J.D. Brodie, and D.M. Adams 1985. Optimizing the sequence of diameter distribution and selection harvest for uneven-aged stand management. For. Science 31(2): 451-462.

Hann, D.W. and B.B. Bare. 1979. Uneven-aged forest management : State of the art (or science). USDA Forest Service Gen. Tech. Rep. Int-50, Inmntn. For. and Range Exp. Stn. Ogden, Utah.

Hirsleifer, J. 1970. Investment, interest, and capital. Englewood Cliffs. 320 pp.

Hirsleifer, J. 1958. On the theory of optimal investment decisions. The J. of Pol. Economics, Aug. 58: 392-352.

Husch, B. 1987. Guidelines for forest policy formulation. FAO Forestry Paper 81, Rome. 86 pp.

Kennedy, J.J. 1985. Conceiving forest management as providing for current and future social value. Forest Ecology and Management 13(12): 121-132.

Leak, W.B. 1964. An expression of diameter distribution for unbalance, uneven-aged stands and forests. Forest Science $10: 39-50$.

Leak, W.B. and R.E. Graber 1976. Seedling input, death, and growth in uneven-aged Northern hardwoods. Canadian J. of Forestry Research $6: 368$ - 374.

Leary, R.A.1970. System identification principles in studies of forest dynamics. USDA For. Service Res. Paper. NC-45, 38 pp.

Marcello, H.B and E.T.Tagudar. 1956. Residual stand in selective high-lead logging. The Philippine J. of Forestry 12 (3-4): 101-115.

Marn, H.M. and W. Jonkers. 1982. Logging damage in tropical high forest. IN: Srivastave etal (eds). Tropical forests: Source of energy through optimisation and diversification. Penerbit Universiti Pertanian malaysia, Serdang-Selangor: 27-38.

Martin, A.J. and P.E. Sendak. 1973. Operation research in forestry; A Bibiliography. USDA For. Service Gen. Tech. Report. NE-8. Northerneastern Forest Experiment Station, Upper Darby, Pensylvania.

Mathews, D.M. 1930. management plant for all age forests. J. of Forestry $28: 57-69$.

McKean, R.N. 1958. Efficiency in governemnt through system analysis. New York.

Mendoza, G.A. and A. Setyarso. 1986. A transition matrix forest growth for evaluating harvesting scheme in
Indonesia. For Ecology and Management 15 : 219 - 228.

Mayer, H.A. 1952. Structure, growth, and drain in balanced uneven-aged forest. J. of Forestry $50: 85$ - 92.

Mayer, H.A. 1943. Management without rotation. J. of Forestry 42: 126-132.

Mayer, H.A.; A.B. Recknagel, D.O. Stevenson, and R.A. Bartoo. 1961.Forest management. 2nd. Ed. The Ronald Prees Co. New York. 282 pp.

Michie, B.R. and J. Buongiorno. 1984. Estimation of a matrix model of forest growth from remeasured permanent plots. Forest Ecology and Management 8(2): 127 - 135.

Modigliani, F. and M.H. Miller 1958. The cost of capital corporate finance and the theory of investment. American Eco. Review. June 1958 : 261 - 297.

Mohd. Shahwahid Bin Haji Otman. 1985. Determining an economic cutting regime for the tropical rain forest. The Malay. Forester 48(1): 57 -74.

Myers, Norman. 1980. Conversion of tropical moist forest: A report prepared by Myers for Committe on Research prioriyies in tropical biology of the National Research Council. National Academy of Sciences. Washington D.C. 205 pp.

Nicholson, D.I. 1958. An analysis of logging damage in tropical forest North Borneo. Malay. Forester 21(4):235-245.

Ortiz-Crespo, F. 1989. The future of the tropical forests. IN : Tropical for ests, botanical, dynamics, specifications, and diversity. Academic Press, San Diego : $335-337$.

Price, C. 1973. To the future: with indifference or Concerns? The social discount rate and its implications in land use. J. of Agric. Econ. 24: 393 -397.

Price, C. 1989. The theory and application of forest economics. Basil Black-well, Oxford. 402 pp.

Rapera, R.B. 1980. A control theory approach to unevenage forest management. Unpublished Ph.D. dissertation. University of Washington, Seattle. $177 \mathrm{pp}$.

Rayes, M.R. 1985. Useful derivation and application of diameter growth of commercial dipterocarp in the Basilan Working Circle. Phil. J. of Forestry 14: 155 - 168.

Rayes, M.R. 1989. An initial guide to the management of residual dipterocarp. The phil. Lumberman 35 (1): 36, 54.

Rayes, M.R. 1989. New logging system. The Phil. Lumberman 35(5): 21 .

Reynolds, R.R. 1945. Growing stock volumes in the allaged forest. J. of Forestry 52: $744-747$.

Rores, C. 1976. Optimal sustainable yield of a renewable resource. Biometrics 32: 945 - 948.

Rores, C. 1978. A linear programming approach to the optimal sustainable harvesting of a forest. J. of Environmental Management 6: 245 -254. 
Schugart, H.H. and D.C. West. 1977. Development of an Applichian deciduous forest succession model and its application to assesment of the impact of the chesnut blight. J. of Env. Management. 5: 161 - 179.

Suparto, R.S. et al. (Ed). 1978. Proceedings of symposium on the longterm effects of logging in Southeast Asia. Biotrop,Bogor. Indonesia.

Tang, H.T. 1978: Regeneration stocking adequacy standards. The Malay. Forester 41(2): 176-181.

Tang, H.T. 1980. Factors affecting regeneration methods for tropical high forests in Southeast Asia. The Malay. Forester 43(4): 469 - 481.

Tinal, U. and J.L. Balanewan. 1974. A. study of mecanical logging damage after selective cutting in the low land forest of East Kalimantan. Biotrop, Bogor Indonesia.
Usher, M.B. 1969. A matrix model for forest management. Biometrics 25(2): 309-315.

Usher, M.B. 1966. A matrix approach to the management of renewable resources with special reference to selection forest. J. of Applied Ecology 3:353-367.

Usher, M.B. 1975. Extension to models, used in renewable resource management, which incorporate an arbitrary structure. J. of .Envi. Management 4 (2) : 123-140.

Wadsworth, R. 1977. A study of diameter distribution of an uneven-aged tropical forest by means of transition matrix model. Unpublished. Ph. D. dissertation. Univ. of Washington, Seattle.

Whitmore, T. C. 1975. Tropical rain forest of Far East. Clarendon Press, Oxpord. 498 pp. 
Appendix 1. The optimal number of tree harvested at variuos cutting cycle and regimes

Lampiran 1. Jumlah pohon yang optimal untuk dipanen pada berbagai rotasi tebang dan regim.

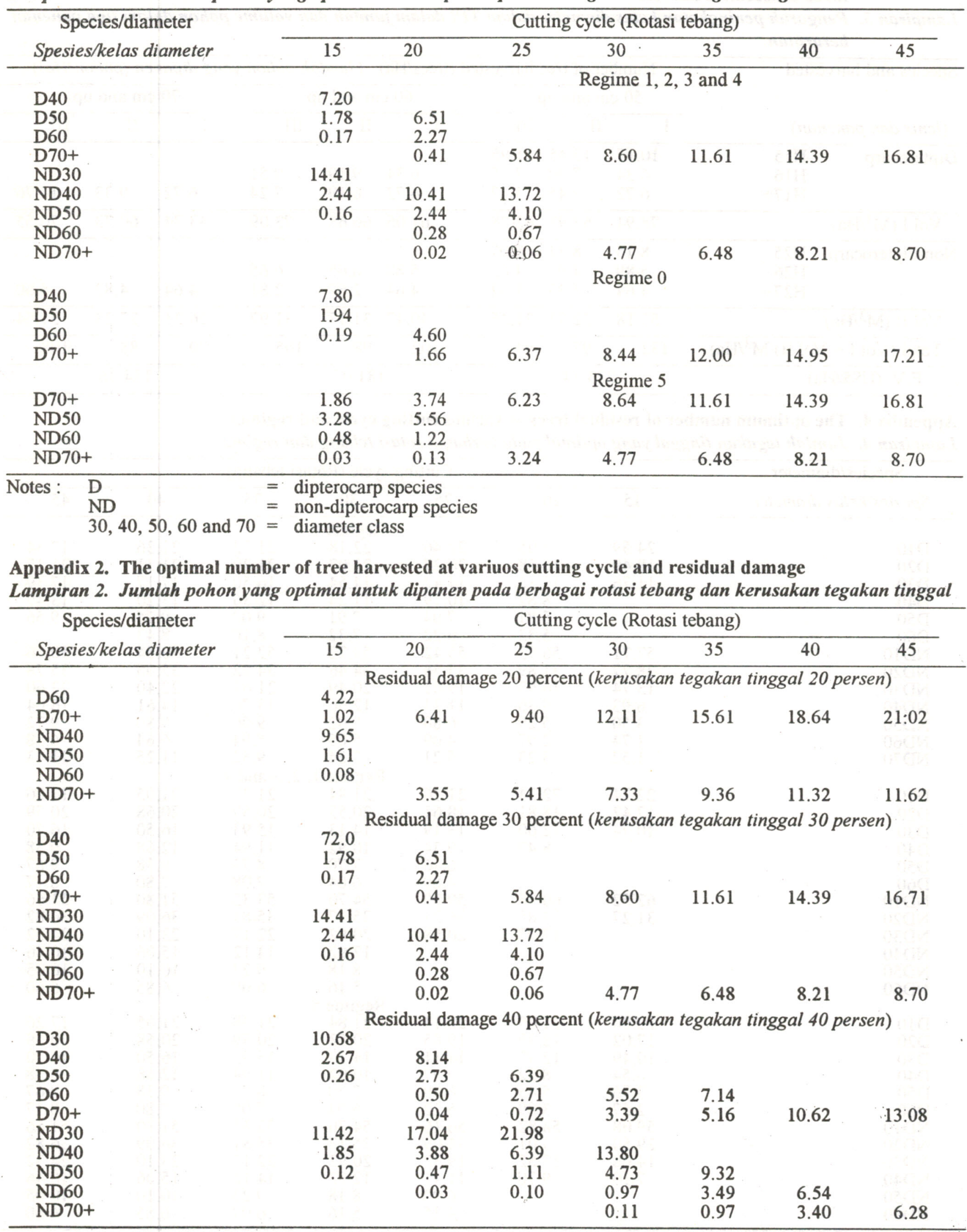

For. Prod. Res. J. Vol. 11 No. 7 (1993) 
Appendix 3. Effect of increase od diameter limit of TPI prescribes on the number and volume of tree harvested in three consecutive harvest

Lampiran 3. Pengaruh peningkatan batas diameter dalam TPI dalam jumlah dan volume pohon dalam tiga panenan berurutan

\begin{tabular}{|c|c|c|c|c|c|c|c|c|c|c|}
\hline \multirow{3}{*}{\multicolumn{2}{|c|}{$\begin{array}{l}\text { Species and harvested } \\
\text { (jenis dan panenan) }\end{array}$}} & \multicolumn{9}{|c|}{ Number of tree harvested (trees/Ha) (Jumlah pohon yang dipanen (pohon/Ha)) } \\
\hline & & \multicolumn{3}{|c|}{$50 \mathrm{~cm}$ and up } & \multicolumn{3}{|c|}{$60 \mathrm{~cm}$ and up } & \multicolumn{3}{|c|}{$70 \mathrm{~cm}$ and up } \\
\hline & & I & II & III & I & II & III & I & II & III \\
\hline \multirow[t]{3}{*}{ Dipterocarp } & H15 & 10.17 & 12.45 & 11.95 & & & & & & \\
\hline & H16 & 6.34 & 7.30 & 7.15 & 6.34 & 9.19 & 9.51 & & & \\
\hline & $\mathrm{H} 17+$ & 6.72 & 3.45 & 3.47 & 6.72 & 6.19 & 7.24 & 6.72 & 9.33 & 11.76 \\
\hline \multicolumn{2}{|l|}{ Vol I $\left(\mathrm{M}^{3} / \mathrm{Ha}\right)$} & 78.94 & 63.93 & 62.78 & 61.05 & 66.68 & 73.09 & 43.74 & 60.73 & 76.55 \\
\hline \multirow[t]{3}{*}{ Non-dipterocarp } & $\mathrm{H} 25$ & 8.15 & 8.34 & 8.07 & & & & & & \\
\hline & $\mathrm{H} 26$ & 5.89 & 4.90 & 4.63 & 5.89 & 6.65 & 6.65 & & & \\
\hline & $\mathrm{H} 27+$ & 4.64 & 1.39 & 1.32 & 4.64 & 2.67 & 2.81 & 4.64 & 4.82 & $5: 60$ \\
\hline \multicolumn{2}{|l|}{ Vol II $\left(\mathrm{M}^{3} / \mathrm{Ha}\right)$} & 53.18 & 32.72 & 31.25 & 40.47 & 31.17 & 31.97 & 26.21 & 27.23 & 31.64 \\
\hline \multicolumn{2}{|c|}{ Total (Vol I + Vol II) $\left.\mathrm{M}^{3} / \mathrm{Ha}\right)$} & 132 & 97 & 94 & 102 & 98 & 105 & 70 & 88 & 108 \\
\hline \multicolumn{2}{|c|}{ F.V. (US\$/Ha) } & \multicolumn{3}{|c|}{223.14} & \multicolumn{3}{|c|}{181.07} & \multicolumn{3}{|c|}{134.38} \\
\hline
\end{tabular}

Appendix 4. The optimum number of residual trees at variuos cutting cycle and regimes

Lampiran 4. Jumlah tegakan tinggal yang optimal pada berbagai rotasi tebang dan regime

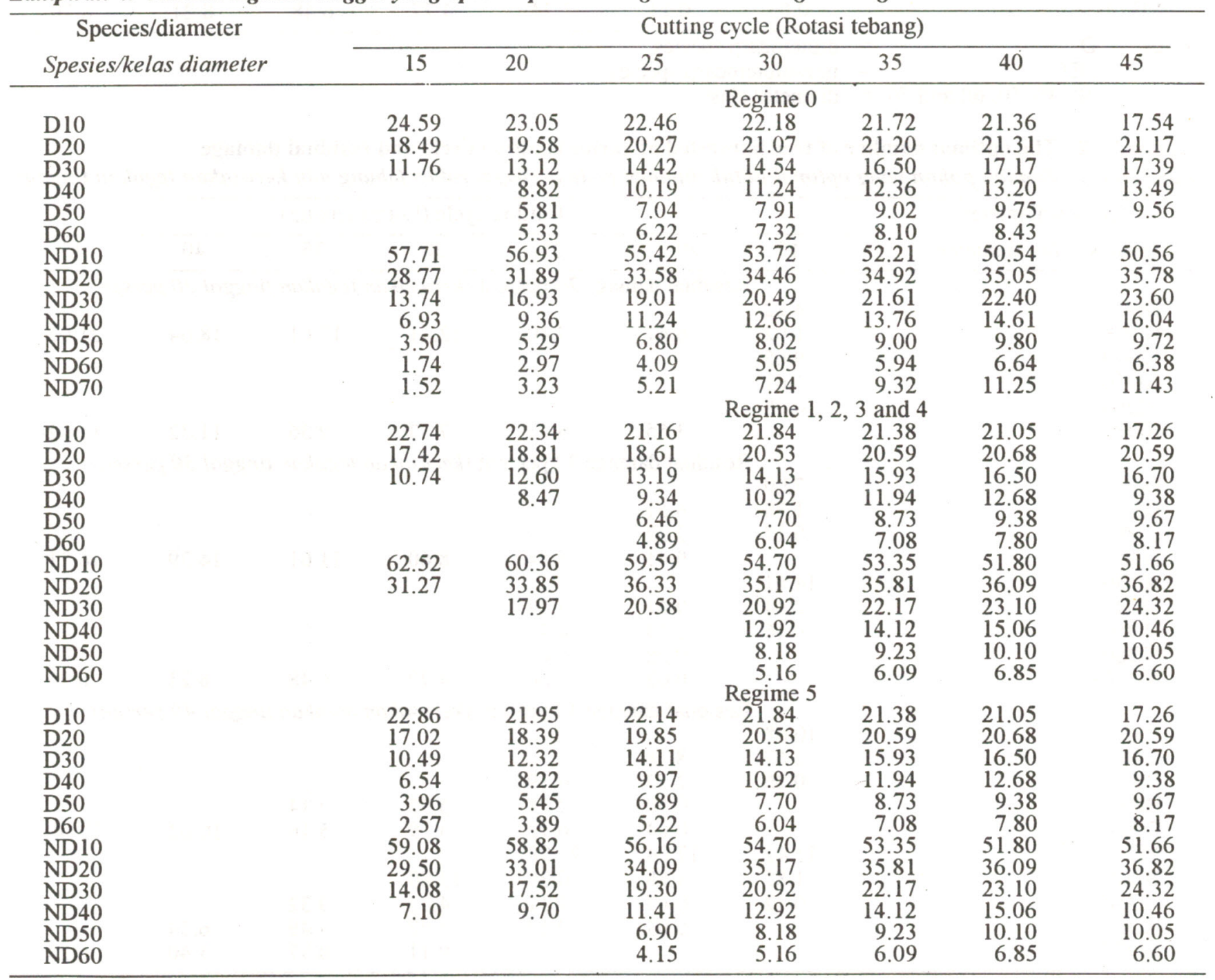


Appendix 5. The optimum number of residual trees at variuos cutting cycle and residual damages

Lampiran 5. Jumlah tegakan tinggal yang optimal pada berbagai rotasi tebang dan kerusakan tegakan tinggal

\begin{tabular}{|c|c|c|c|c|c|c|c|}
\hline \multirow{2}{*}{$\begin{array}{c}\text { Species/diameter } \\
\text { Spesies/kelas diameter }\end{array}$} & \multicolumn{7}{|c|}{ Cutting cycle (Rotasi tebang) } \\
\hline & 15 & 20 & 25 & 30 & 35 & 40 & 45 \\
\hline & \multicolumn{7}{|c|}{ Residual damage 20 percent (keruisakan tegakan tinggal 20 persen) } \\
\hline D10 & 24.23 & 24.94 & 24.61 & 24.41 & 23.94 & 23.66 & 18.38 \\
\hline D20 & 20.12 & 22.20 & 22.82 & 23.43 & 23.19 & 23.32 & 23.25 \\
\hline D30 & 14.04 & 16.34 & 17.44 & 16.85 & 18.79 & 19.19 & 19.19 \\
\hline D40 & 9.92 & 12.15 & 13.41 & 14.12 & 15.01 & 15.58 & 15.48 \\
\hline D50 & 6.80 & 8.82 & 10.06 & 10.66 & 11.70 & 12.22 & 12.23 \\
\hline D60 & . & 7.02 & 8.34 & 9.05 & 10.14 & 10.78 & 10.93 \\
\hline ND10 & 67.86 & 61.98 & 60.34 & 58.77 & 57.50 & 56.01 & 56.38 \\
\hline ND20 & 38.52 & 38.06 & 39.14 & 39.69 & 39.98 & 40.01 & 40.82 \\
\hline ND30 & 21.44 & 22.80 & 24.46 & 25.61 & 26.50 & 27.12 & 28.28 \\
\hline ND40 & & 14.30 & 16.06 & 17.34 & 18.30 & 19.00 & 13.21 \\
\hline ND50 & & 9.20 & 10.84 & 12.06 & 13.01 & 13.74 & 13.27 \\
\hline \multirow[t]{2}{*}{ ND60 } & & 5.95 & 7.35 & 8.43 & 9.38 & 10.08 & 9.40 \\
\hline & \multicolumn{7}{|c|}{ Residual damage 30 percent (kerusakan tegakan tinggal 40 persen) } \\
\hline D10 & 22.74 & 22.34 & 21.16 & 21.84 & 21.38 & 21.05 & 17.26 \\
\hline D20 & 17.42 & 18.81 & 18.61 & 20.53 & 20.59 & 20.68 & 20.59 \\
\hline D30 & 10.74 & 12.60 & 13.19 & 14.13 & 15.93 & 16.50 & 16.70 \\
\hline D40 & & 8.47 & 9.34 & 10.92 & 11.94 & 12.68 & 9.38 \\
\hline D50 & & & 6.46 & 7.70 & 8.73 & 9.38 & 9.67 \\
\hline D60 & & & 4.89 & 6.04 & 7.08 & 7.80 & 8.17 \\
\hline ND10 & 62.52 & 60.36 & 59.59 & 54.70 & 53.35 & 51.80 & 51.66 \\
\hline ND20 & 31.27 & 33.85 & 36.33 & 35.17 & 35.81 & 36.09 & 36.82 \\
\hline ND30 & & 17.97 & 20.58 & 20.92 & 22.17 & 23.10 & 24.32 \\
\hline ND40 & & & & 12.92 & 14.12 & 15.06 & 10.46 \\
\hline ND50 & & & & 8.18 & 9.23 & 10.10 & 10.05 \\
\hline \multirow[t]{2}{*}{ ND60 } & & & & 5.16 & 6.09 & 6.85 & 6.60 \\
\hline & \multicolumn{7}{|c|}{ Residual damage 40 percent (kerusakan tegakan tinggal 40 persen) } \\
\hline D10 & 20.89 & 19.78 & 18.96 & 18.73 & 18.56 & 18.22 & 15.72 \\
\hline D20 & 14.78 & 15.74 & 16.15 & 17.01 & 17.61 & 17.72 & 17.88 \\
\hline D30 & & 9.54 & 10.60 & 11.11 & 13.00 & 13.65 & 14.22 \\
\hline D40 & & & 6.83 & 7.87 & 9.09 & 9.88 & 10.50 \\
\hline D50 & & & & 5.14 & 6.18 & 6.84 & 7.40 \\
\hline D60 & & & & & & 5.32 & 5.86 \\
\hline ND10 & 52.99 & 54.39 & 54.40 & 51.50 & 49.25 & 47.13 & 46.19 \\
\hline ND20 & 23.32 & 27.90 & -31.01 & 31.63 & 31.96 & 32.04 & 32.36 \\
\hline ND30 & & & & 17.26 & 18.42 & 19.33 & 20.35 \\
\hline ND40 & & & & & 10.73 & 11.64 & 7.98 \\
\hline ND50 & & & & & & 7.19 & 7.29 \\
\hline ND60 & & & & & & & 4.41 \\
\hline
\end{tabular}

For. Prod. Res. J. Vol. 11 No. 7 (1993) 